\title{
Classé, Surclasser, Déclassé, or, Roland Barthes, Classification without Class
}

\author{
Andy Stafford \\ Rien n'est plus essentiel à une société que le classement de ses langages. \\ Changer ce classement, déplacer la parole, c'est faire une révolution.
}

Roland Barthes, Critique et verité

HE AIM OF THIS ARTICLE is to suggest, in both a peremptory and
a provisional fashion, that classification - and associated activities of
declassifying or unclassifying - is a key theme, if not the key theme, in the work of Roland Barthes. Classification is an activity in which we, as researchers in literary and cultural studies, are constantly involved; and yet the ordered, scientific pigeonholing inevitably entailed by classifying seems antithetical to the creative, 'free' nature of the literary and cultural objects that we analyse. It is almost as if humanities study - as a structured method of taxonomy and variation - is not, or should not be, part of academia; for the aims, methods, and objects of humanities analysis are seemingly traduced by the need for a university-measurable output (not to mention 'impact'), and are constantly 'boxed' into tweetable sound-bites fit for the auditor and paymaster and no longer for the academic community. One of the enduring skills of Roland Barthes's radical approach to this conundrum is his ability to navigate between, on the one hand, the desire for understanding and explaining (including classifying) aspects of the contemporary world and, on the other, the refusal to cover them with catch-all, simplistic, and ideologically-controlled generalisations. As this article intends to show, Barthes's suspicion of classification extends to the very way in which we interact with others, with the Other, in society. Classification in Barthes's research is clearly a useful tool-for the study of fashion forms, for the codes of literary meaning, for understanding language and communication; but it also locks humans, their creative capacities, and the ways of negotiating their personal identities and freedoms into a straitjacket of stereotypes, solitude, and social alienation.

However, trying to understand the function of classifying in Barthes's work is possibly not a good idea for two reasons. First, as the "Barthes" entry by Peter France in the Oxford Companion to French Literature (1995) suggests, Barthes is "a writer who evades classification." Second, in her 2012 biographical essay, Roland Barthes: Au lieu de la vie, Marie Gil presents this classification-evader, very persuasively, as an "oscillator." She shows Barthes flitting 
constantly between opposing positions, holding dialectical tensions in nonsynthesised open-endedness; and (in the later stages of his career) Barthes is seen in this optic valorising the "suspension of judgement," the Wou-wei of Taoism, as a radical intellectual strategy in the face of society's cloying "doxa" that acts against the West's 'figures' of "vouloir saisir, dominer, vivre, imposer sa vérité." ${ }^{2}$ Furthermore, two authoritative bibliographical sources-Gilles Philippe's "mots clés" in his Bibliographie Barthes (1996) and Neil Badmington's four-volume critical anthology (2010) - contain no reference to Barthesian ideas on classification. ${ }^{3}$ Not only does this omission obliquely justify Peter France's bold suggestion, but it also allows us to make a singular reading of singularity in Barthes's work. We concentrate in this article, then, on the notion of exception, of the scandalously unclassifiable. How does Barthesian thought move from classification to declassification, from social-class determinism to the "intellectuel déclassé," and can this generalised shift across his career help us to reclaim the humanities from the philistinism and populism of 'impact'- and results-led research? ${ }^{4}$ Can deeming Barthes to be an "oscillator," as Marie Gil has done, fully account for this trajectory?

In her biography Marie Gil presents her subject as dualistically constructed. It is a fascinating biography which reads Barthes's life-appropriately enough - as a 'text.' Gil's metaphor of Barthes as an oscillator is the basis of her psychoanalytical approach, and, as an essai biographique, her 'fictional' reading of Barthes's life as literary text seems to be parametric to the writer's own concerns. And yet, the main point of her biography- that the fundamental trauma of Barthes's life (the death of his beloved mother, towards the end of his own life) structures our view of his life (backwards, as it were) - seems at odds with its subject, overly teleological in its presentation of this moment in 1977 as the defining event of Barthes's life. ${ }^{5}$ Indeed, the 'closure' that this highlighted event of his mother's death invites - according to which Barthes, once again, is viewed overwhelmingly via his 'late' career-seems to reinstate, in Gil's teleological approach, that very spirit of "vouloir-saisir" against which Barthes's lectures at the Collège de France (and the Fragments d'un discours amoureux of 1977) had tried to suggest radical alternatives. Instead, in this article, by considering Barthes's "oscillating" attitude to classification (applied to himself, to society, to research), we will see that, from the earliest stages of his career up until his final writings, Barthes sought ways out of classification. ${ }^{6}$ We could therefore invoke a different psychoanalytical metaphor, such as that of the Houdini-escapologist recently investigated by the British psychoanalyst Adam Phillips. ${ }^{7}$ However, the competing metaphor that we will use, for reasons to follow, will be drawn not 
from Freud, Lacan or Winnicott, but from Marx. Our survey of Barthes's attitude to classification begins, appropriately enough then, with his own social, personal, and class position.

\section{Classé—pupille de la nation}

Par la pauvreté, il a été un enfant désocialisé, mais non déclassé. (Roland Barthes, OC $4: 625)$

$[U] n$ quart de bourgeoisie propriétaire, un quart d'ancienne noblesse, deux quarts de bourgeoisie libérale, le tout brassé et unifié par un appauvrissement général. ("Réponses" [1971], OC 3:1024)

The very first form of classification is the one dealt with by society. Not only a war orphan, socially defined, Barthes was also locked away in a sanatorium during early adulthood, his tuberculosis requiring a distinct classification of his body, and removing him from the experiences of the war, in a social isolation that rested on the fear of contagion, stymieing his academic and professional career. To his war-orphan, "tubard," professionally-excluded status must be added his (largely hidden) homosexuality and even his left-handedness. The marginalized and marginal social and class position that classified Barthes - marked by impecuniousness for over half of his life (until the inheritance from his maternal grandmother, Noémi Révélin, in 1954) —would go on however to be a key way for Barthes to escape the social 'hole' in which he finds himself in 1945; Barthes's rather singular social position was to become the space within which his writing was to play out. Indeed, it was in this writing that he showed himself to be acutely sensitive to singularity and to exceptionality, which in his early career was illustrated by the most curious of animals used as a metaphor.

Early in Barthes's writing career after the war, the eighteenth-century Swedish naturalist Carl Linnæus appeared as an important reference. In his acts of scientific and zoological classification (distinction, division, designation), Linnæus had stumbled during the eighteenth century on an amphibious but mammalian animal from Tasmania, the duck-billed platypus. In a number of Barthes's pieces in the early 1950s the "ornithorynque" becomes a metaphor for the unclassifiable, the exception. We will see how this "paradoxical platypus" (to quote Brian Hall) becomes linked in Barthes's work first to singularity, including specificity, and then to a critique of analogy that betrays an acute awareness of the semelfactive (that which happens, irreversibly, only once), challenging classification's claims to comprehensiveness. ${ }^{8}$

On a number of occasions in his writings between 1950 and 1964, Barthes refers to Linnæus's seminal Systema naturce (first published 1735, continually 
updated until the thirteenth edition in 1770), and in particular to the "paradoxa": the collection of "cryptids," the odd, inexplicable, unclassifiable, creatures - the Yeti, Loch Ness Monster or the Sasquatch - around which there was no scientific consensus on classification. But instead of taking Jorge Luis Borges's route of imagining "paradoxa"-mythical animals-Barthes uses the "paradoxa" as part of a critique of analogy. This is the period 1950-1952, the beginning of Barthes's most Marxist writing - be it in the popular theatre movement or in his numerous critiques of bourgeois and petty-bourgeois ideological distortionsin which he displays an acute sensitivity to social classification. ${ }^{9}$

The first major reference to the platypus in his writings comes with a Marxian defence of history. In the voluntarist mode of social explanation typical of post-war Trotskyism in France-whereby the "masses" ("the people" in Micheletian language) are unconstrained by determining structuresBarthes deems that History (with a capital H) is made, not by the structural, systemic changes that he will later invoke, but by the people. Thus, in his 1950 review in Combat of André Joussain's recent book, La loi des révolutions, Barthes rejects Joussain's laws behind history's social upheavals, criticizing Joussain's formulaic understanding of the way change has taken place for the way in which it alienates history from human agency. ${ }^{10}$ For example, Barthes is outraged that "[1]a prise de pouvoir par Mussolini ou par Hitler, la révolution nationale [...] de 1940 sont [...] des révolutions à l'égale de la révolution russe." For by trying to deduce a law of revolutions from a comparison of ten very different historical incidents, Joussain was simply doing what historians had done "de Herder à Hegel, de Montesquieu à Michelet." Joussain's "dégradation des révolutions" by his erroneous comparisons was possible only because he considered "ses révolutions du plus haut possible, c'est-à-dire du point de vue le plus formel." It was Joussain's scientific formalism that was at fault: "il lui suffit de méditer 'scientifiquement' sur les 'formes' de l'Histoire au détriment de son contenu," argued Barthes (OC 1:101). Joussain's use of an exhaustive (Linnæus-style) catalogue of factors (such as psychological, social, permanent, periodical, intellectual, historical) were informing his distant and content-less explanations and comparisons, and, as with the undermining of Linnæus's scholastic attempts to classify all animals by the existence of the unclassifiable, Joussain's attempt to understand the laws of revolutions was thwarted by revolution itself:

On croit lire une classification de Linné. Mais de même que dans une planche de Linné il reste toujours à part quelque animal scandaleux, l'ornithorynque par exemple, placé sous la rubrique pudique de "paradoxa" faute d'avoir pu trouver son ordre ou sa classe, de même les tableaux de M. Joussain comportent toujours, finalement, un événement solitaire, inaliénable, paradoxal et 


\section{L'ESPRIT CRÉATEUR}

qui gêne tout classement: la révolution elle-même qui, de son volume spécifique, déborde les classements scolastiques à travers quoi on voulait la déchirer. (OC 1:101)

Rather than the comparative history that Joussain invoked, typical of historywriting since the romantic period, what is needed, according to Barthes, is an explanation of revolutions (indeed, of history) that covered a number of concrete dimensions ("économiques, sociales, intellectuelles, etc."), after which the problem for historians is to achieve a synthesis of the crucial factors in human society. For Joussain, on the other hand, history was nothing more than a 'sum' of causes, accidents, and individualities which, when simply mixed together, could not account for history's diversity of events. Abstracting events from their individual context not only denied the specificity of each event, it also helped to deny actants any effect in and on history:

[O]n n'a pas le droit de rapporter les déterminations d'un paysan de Luther à celles d'un avocat de la Constituante ou d'un ouvrier de la Commune; on n'a pas le droit de substituer à ces figures spéciales, un mécanisme général, dont les révolutions tomberaient, plus ou moins mûres, comme les mêmes fruits d'un même arbre. (OC, 1:103)

Barthes's central point seems to be that the denial of humanity's ability to make history, the alienation of history from the masses, is integral to the formalistic and mechanical way in which Joussain classified revolutions and then analogically equated radically different historical moments. Just as Linnæus's classifications of animals always left out an animal that they could not fit in, so Joussain's attempt to classify social upheavals using historical analogies failed to account for the specificity of each revolution.

Barthes's critique of historical formalism was to appear again a year later in two reviews of a short 1950 sociological study of Marxism by Roger Caillois called Description du marxisme. ${ }^{11}$ It is in his second review of Caillois's book, "À propos d'une métaphore (le marxisme est-il une 'église'?)," published in Esprit in 1951, that Barthes carries on the critique of analogy and metaphor. Here, he attacks the analogical manner in which Caillois equates Marxism with the Church, as a faith not a science:

Cette méthode consiste à dégager de deux faits historiques différents, des caractères semblables et généraux, d'amorcer une sorte de constante de l'Histoire, de ramener marxisme et chrétienté dans les limites d'une Histoire purement institutionnelle, objet d'une sociologie des Formes. (OC 1:135)

Caillois too was using, suggests Barthes, the nineteenth-century technique of explanation, the analogy. We have seen how his critique of Joussain's account of the laws of revolution points to the manner in which the 'content'-or 
specificity - of history had been evacuated; now Caillois's "histoire analogique" offered, in a very similar way, a shallow view of history, in the form of a philosophy of history:

[L]'analogie était la méthode scientifique par excellence, parce qu'au XIX ${ }^{\mathrm{e}}$ siècle, la Science [...] ne pouvait se contenter d'une pure description des phénomènes historiques; il lui fallait à tout prix en trouver l'ordre secret et moteur, la raison, la loi, l'esprit, l'organisation, mot qui commence alors sa fortune. (OC 1:135-36)

Barthes is making an important connection between nineteenth-century analogy and the epistemological problem posed by the duck-billed platypus. The failure of science to account for, and classify satisfactorily, the ornithori anai$n u s$, as Barthes seemed to be intimating, resembled Joussain's and then Caillois's use of analogy which, Barthes suggests, masquerades as scientific sociology (of revolution in the former and of Marxism in the latter). Barthes never mentions that Linnæus abandoned the "paradoxa" in the sixth edition of 1748, but it is clear that the 'scandal' that Caillois saw in Marxism's popularity in 1950, and the consequent analogy with religious irrational and fanatical belief, was precisely the type of exception presented by the duck-billed platypus: if you cannot explain it, analogize it. Of course, Barthes's 1950s essays in Mythologies are the antidote to this analogising, as he vaunts the radical act of explanation, the specificity of History, against the 'alibi' of analogy and what we might call the superficiality of historical formalism.

However, at a key moment at the end of Mythologies, in "Le mythe, aujourd'hui," Barthes suggests - despite his earlier critique of Joussain and Caillois - that "l'étude spécifique des formes ne contredit en rien aux principes nécessaires de la totalité et de l'Histoire," and that, though a little historical formalism tends to distance history, "beaucoup y ramène" (OC 1:825-26). Defining semiology here as a "science des formes," Barthes's work from 1957 into the mid-1960s will not only use semiology to study "des idées-en-forme," but also deploy classification in its methodology; thus the ideological criticism of classification in his earlier Marxism has become a radically formalist critique of the distortions of ideology that itself uses classification. Barthes had already hinted at this in his 1954 book on Jules Michelet when he suggested that his account of the nineteenth-century historian's writing of history was but a "précritique" to a full-blown ideological critique (OC 1:293). 


\section{L'ESPRIT CRÉATEUR}

\section{Surclasser}

Le langage est une législation, la langue en est le code. Nous ne voyons pas le pouvoir qui est dans la langue, parce que nous oublions que toute langue est un classement, et que tout classement est oppressif[.] ("Leçon" [1978], OC 5:431)

Despite a suspicion of classification, Barthes's research in the 1960s relies heavily, if only methodologically, on the act of classifying. This is especially true in relation to clothing and fashion, where the item, in order for its function to be understood, first needs to be subject to an extensive taxonomy. Having abandoned, by 1959, any attempt to understand how clothing forms change and are modified over history, Barthes makes three important decisions in his work on clothing. First, following the advice of Claude LéviStrauss, he sets out to consider clothing uniquely via the written discourse attached to it; second, he relinquishes the historical, or diachronic, dimension in order to concentrate on contemporary, or synchronic, manifestations of clothing; this leads to the third innovation, that of studying fashion, women's fashion, as a nexus of novelty, innovation, and social function. In this research in the early 1960s in particular-but also in his 1966 collaborative work on the structuralist analysis of narrative-Barthes relies heavily, if only tactically and provisionally, on the act of classifying; and it is in this "surclassement"- over-classification - that the platypus's singularity is given a new outlet in the 1960s.

Before starting his doctoral thesis on fashion, Barthes had already found the two elements of his analysis: written clothing as part of a social system and then, in the wonderful 1961 essay on gemstones and jewels, "Des joyaux aux bijoux" (OC 1:1089-93), the fundamental, if not determining, role of the detail. This latter article is important because, on the one hand, it shows the growing awareness of arbitrariness in fashion: as long as the / a detail fundamentally alters the outfit, then fashion can be shown to work, and can move forward; at the same time the essay on gemstones shows the architectonic, chthonian links that certain 'natural' but rare objects have for humans, and underlines the function that their materiality fulfils in our unconscious and primal desires. So, in the midst of the systematic and scientific attempt to account for (women's) fashion and its language of persuasion and seduction - which is semiologically classified, first in his 1960 article " $L e$ bleu est à la mode cette année" (OC 1:1023-38) and then in Système de la mode in 1967-Barthes comes to an important structural discovery. First, a fashion ensemble can be radically altered by the addition of the smallest of details (a brooch, button or other accessory); second, the significance of a phenomenon 
within a totality (such as a literary text or a fashion ensemble) is not dependent on its size or its regular occurrence, but on its structural function within the totality. In other words, it is the combination, la combinatoire (OC 2:1309), and not the frequency or the relative 'weight' of each phenomenon, that determines meaning and explains functions; crucially for our argument, the combinatoire, though initially reliant on classification, actually points to classification's inability to perform explanation, and it does so by going beyond its phenomenal, objective act of listing. However, it is only during acts of classification - an artificial, analytical act of taxonomy that Barthes borrows from linguistics - that this operation of combining can be seen to be working. Thus, it is on the level of their relative functions that Barthes classifies fashion items within a fashion whole, or narrative functions within a particular story (as illustrated in his 1966 "Introduction à l'analyse structurale des récits" [OC 2:828-65]). However, this procedure requires a preliminary and provisional act of taxonomy in order to establish structural significance. This is at once a tightening of the contextual argument that he had used to criticize Joussain's and Caillois's formalism, and an attempt to overcome the exceptionality posited by the platypus, by showing how the detail, a form of exception, functions within a structure. In a sense then, the 'detail' of history and of political sociology whose absence he angrily regretted, respectively, in Joussain's and Caillois's books, is now, in this 1960s structuralist phase, being used to analyse fashion forms and literary functions. The exception illustrated by the platypus has been tamed, we might say, by showing how the detail functions within the whole. ${ }^{12}$ So classifications are the system slowed down, artificially stopped, yet subsequently bracketed, if not abandoned, so that the combinatoire can then be seen to operate: the tighter the classification, the clearer the combining functions. However, this model comes full circle once the detail is introduced to the fashion ensemble. The detail both conjures away and reaffirms the classification, by moving the overall meaning of the combinatoire onto a new level. The detail ('scandalous' as the platypus was for Linnæus) is an operative feature of the fashion ensemble precisely because it stands out(side) from (of) it: the detail seems to have no structural or classificatory importance, and yet it functions as a fashion game-changer.

It is precisely within this newly adopted structuralist paradigm of the combination that Barthes's Linnæus reappears in relation to the platypus in 1962, in his article on the "Structure du fait divers." Here the fait divers "procéderait d'un classement de l'inclassable" (OC 2:442) ${ }^{13}$ Barthes suggests furthermore that, given that the content of the fait divers depends on where it is published, it would be better to look at it structurally ("une différence de structure et non 
plus une différence de classement" [OC 2:442]). In other words, like the duckbilled platypus, the fait divers needs to be considered not for its classificatory identity (which is fruitless because it is entirely singular, irreducibly semelfactive), but for its function within other news reports. Thus, Barthes has hoisted the platypus example out of his 1950s critique of historical formalism and brought it to bear on the function of phenomena within a totality. Barthes's metaphor (analogy?) remains the same - the platypus escapes classificationbut he now seems to be suggesting that structure trumps classification, that functionality within a totality undermines, or (finally) does away with, the need for taxonomy. For example, Éléments de sémiologie, published in 1964, submits the social phenomena of signs and communication, temporarily, to a rigorous classification, by dismantling the workings of various objects such as fashion and filmic and literary texts, but only in order to show how meanings are generated in relation to each other. Thus Éléments de sémiologie, involving four classifications-language and speech, signifier and signified, syntagm and system, denotation and connotation - reads the fourth chapter of Saussure's Cours de linguistique générale in order to show that meaning is nothing but an order of "divisions," an "arthrologie" or "science des partages" (OC 2:671). But these divisions are again (as with revolutions and Marxism) dependent upon the specific context in which they appear, and, crucially now in this structuralist period, upon the structure in which they function.

At the very same time, Barthes seems highly critical of the separation or 'arthrologie' that he was tentatively advocating. In the 1964 article on "Les planches de l'Encyclopédie," he makes a link back to his view of social class in seventeenth-century Dutch painting (cited in note 9). Quoting Bernard Groethuysen's description of the Renaissance as a "connaissance aventureuse," as opposed to the "savoir d'appropriation" of the Encyclopédie published over two centuries later (and based on the fragmenting of objects), Barthes now appears deeply wary of acts of classifying: "[O]n ne peut séparer sans finalement nommer et classer, et dès lors, la propriété est née. [...] La nomenclature encyclopédique [...] fonde en effet une possession familière" (OC 2:1350-51). All attempts at classification-be they of animals in Linnæus, the machinery described in the Encyclopédie, revolutionary moments in history or the sociological forms of political systems such as Marxism - end up denying specificity. Thereby these attempts tame and domesticate ideologically that which challenges classification and that which could subvert the naturalisation of ownership and of social control.

One major option now seems open to the semiologist confronted with the dilemmas of classification. However, before moving on to the final section on 
the "déclassé," we must consider the period 1967-1969, in which Barthes's complex attitude towards classification is further manifest. Reducing narrative to its functions and indices, then analysing the "ancienne Rhétorique" in 1966 for its structural significance (OC 3:527-601), results in the most classificatory work of Barthes's career in the 1968-1969 seminar on Balzac's story "Sarrasine," published as $S / Z$ in 1970 . Already in his 1968 piece on Flaubert's short stories, "L'effet de réel" (OC 3:25-32), he had shown that "tout signifie." So, if everything signifies, if all details of a story mean, how do we classify these details now as functions and indices?

Barthes's response is the use of codes in $S / Z$. Many critics have regretted the manner in which Barthes reduces the multiple codes of Balzac's story to just five; for example, Philip Thody suggests that the deployment of only five codes "for an infinitely meaningful text is a shade miserly." ${ }^{.14}$ But isn't that the point of $S / Z$, that is, how to build up the structure of a text only to destroy the classification through the text's plural voices and its (infinite) structuration through the combination of the codes? ${ }^{15} S / Z$ illustrates, then, not so much Marie Gil's oscillator theme, but rather Barthes as Houdini: the tighter the classification, the better the subsequent declassification. In this escapologist optic, $S / Z$ becomes the decentred record of the seminar across 1968. The "Sarrasine" seminar in deploying the critical analogy of proportion (what we might call "parametrism"), gives way, in $S / Z$, to a new essayistic form, a form that was unclassifiable then and perhaps still is today. The notion of the "paradoxa" that we saw in the platypus now becomes attached to Balzac's story "Sarrasine"; but, crucially for our argument here, $S / Z$ becomes the singular essay on the plural, and, at the same time, a semelfactive rewriting of Balzac: a set of paradoxa from which only the essay can help Houdini-Barthes to escape and emerge into another period.

Indeed, in the post-68 world, Barthes recognises the lack of room for manoeuvre, and he now turns to the question of the 'institution.' Dovetailing with the work on the "institué" by René Lourau, Barthes begins, in 1970, to see a link between institution and classification:

[L]es institutions ou l'institution elle-même, l'institution sociale se donne toujours comme tâche de surveiller le sens, de surveiller la prolifération des sens; [...] dans l'interprétation des textes littéraires s'exerce aussi une sorte de surveillance de l'institution, de l'Université en l'occurrence, sur la liberté d'interprétation des textes. ("Une problématique du sens," OC 3:510) ${ }^{16}$

Philology, suggests Barthes, is a science whose role is to "surveiller ces excès polysémiques: presque tous les combats idéologiques de l'humanité, en tout cas de l'humanité occidentale, depuis des siècles, sont toujours des combats du sens." Typical of Barthes's contradictory attitude to classification, he pro- 
poses a "tour d'horizon très vaste et par conséquent très peu rigoureux, une sorte de classification de ce que j'appellerai les différents régimes anthropologiques du sens," in which he sees three components, "monosémie," "polysémie," and "asémie" (OC 3:510-11).

The period 1967-1971 seems to be a key Houdini moment for Barthes that goes via a "dé-institution." The "Sarrasine" seminar of 1968-1969 and the "Lexique de l'auteur" seminar of 1973-1974 (which then becomes Roland Barthes par Roland Barthes in 1975) could be considered, paradoxically, as precisely a form of "disinstitution," in that the 'objectivity' of social-science research is dissolved across an objectified writing self that is radically subjective in its literary approach. ${ }^{17}$ In contradistinction to the seminars that Barthes led in the 1960s involving the sustained attempt to classify (if only temporarily) functions and indices, the period that follows May 1968 is marked by a much more micro-structural attention to the detail. It is the singularity of the literary text, along with structuralism's tendency to homogenize all texts into a relatively small number of narrative functions, that begins to turn Barthes away from the super-classifications of the 1960s. The opening page of $S / Z$, in 1970 , which signals the move away from "la science indifférente" (OC 3:121), leads to the opening page of Le plaisir du texte in 1973, in which he imagines a "fiction d'un individu [...] qui abolirait en lui les barrières, les classes, les exclusions" by using "la contradiction logique" (OC 4:219).

One of the key elements in this 'late' suspicion towards classification is in Barthes' work and writing on his own 'image' in 1970s French society, involving a series of classifications that he begins to interrogate in the 19731974 seminar "Le lexique de l'auteur." One strategy of undermining the classifications to which he feels exposed-like a "parcelle de pomme de terre [...] durcie, rissolée, caramélisée [...] une frite," the famous metaphor used in his intervention at the Colloque de Cerisy in 1977, "L'image" (OC 5:517) - is to use the third person in Roland Barthes par Roland Barthes. Here, it is as if by externalising the voice of the self, when writing about his self, that the writer can crack open the classificatory straitjacket that society continually places upon that self. This strategy is part of what Barthes calls the "atopique," taking the self out of the place to which it is assigned. It is precisely the atopic that we will now look at in relation to classifications of the self, and specifically to those of social classification. 


\section{'Déclassé'}

Qui ne sent combien il est naturel, en France, d'être catholique, marié et bien diplômé? (Roland Barthes, OC 4:706)

Fiché: je suis fiché, assigné à un lieu (intellectuel), à une résidence de caste (sinon de classe). (Roland Barthes, OC 4:629)

In the later stages of Barthes's career, his ambivalent attitude towards classification seems to harden: not just in personal, but also in epistemological and linguistic terms, including a heightened awareness of the negative role of the "adjective" ("Le grain de la voix," OC 4:148-56). At the same time, following his attribution of the title of "classificateurs" of new languages to the unlikely combination of Sade, Fourier, and Loyola in his 1971 essay, all classifications (including the oscillatory declassification) are now impulses for writing. For example, Barthes uses an alphabetical order of his fragments as a false classification, that is, arbitrary or in-between, falsely 'motivated'. Indeed, according to Cécile Hanania, Barthes's use of etymology is just this: an arbitrary oscillation between "classer et découper" on the one hand, and an application of the key structuralist denial of an origin which potentially undermines all etymology, on the other. ${ }^{18}$ The dialectical outcome of this oscillation in his work is a constant translation, an inexorable circulation, of the etymon. It is, as Hanania hints (16), the mature, later Barthes who begins to play with etymology in order to declassify meaning. A similar point could be made in relation to his use of neologism.

As suggested by the innovative form of his 1970 essay $S / Z$, 'genre' questions also begin to undermine classification in the later Barthes: the "essai," the academic lecture, the seminar, journalism, the "recueil," all become formally interchangeable. From $S / Z$ onwards, it is the "livre-cours" (texts emerging from teaching) and travel-writing (in Japan and China) that come to the fore, built overwhelmingly on the writing of the fragment - to the point that we might wonder, following Ginette Michaud's linking of the detail and the fragment in their "détotalité," whether the fragment itself declassifies. ${ }^{19}$ Indeed, all oscillatory attitudes towards classification now lead to writing, but not in any fixed form, and involve what Patrizia Lombardo has called "la quête existentielle d'une forme." ${ }^{20}$ For example, in the Carnets of his 1974 visit to China with Tel Quel, Barthes is famously short on commentary (see his account in Le Monde on his return, "Alors, la Chine?," OC 4:516-20), where, unlike his visits to Japan in the late 1960s, "[Il] ne trouve, en fait, rien à noter, à énumérer, à classer"; and yet, he transforms this into writing. ${ }^{21}$ Again, in his 1975 biography of self, Roland Barthes par Roland Barthes, the three pleasures related to the spatial arrangements for "jouissance" are listed 
as painting, writing, and classifying. Similarly, the "pharmakon" view of French vocabulary in Fragments d'un discours amoureux, in which language is presented as both illness and remedy, is but the premise for a "point de départ" of writing. Indeed, the "fuite en avant," the image "déclassée," onomastics, the notions of "perte" and of dissolution of self, the invocation of the spiral, all seem aimed at declassifying the self. It is the 1977-1978 lectures on "Le neutre" that provide the theoretical basis for these ideas.

In Le neutre Barthes defines this unclassifying as the "dénégation de tout unique et cependant reconnaissance de l'incomparable," what he calls the "science des moires" (Le neutre 118). But crucially he realises also that he (we) cannot get away from the Other, be it in love, in his fantasy of living together (in the 1976-77 lectures, Comment vivre ensemble. Simulation romanesque de quelques espaces quotidiens. Cours et séminaires au Collège de France), or in his family and home-life, especially with his mother. All of these relations with the other come into conflict with notions of classification. It is now that the 'late' Barthes begins to glimpse what the Marquis de Sade referred to as "délicatesse," the 'tact' required in maintaining the singularity of the self, the uniqueness of person, what he terms the 'aristocratic' notion of distinction in relation to the social combinatoire. The aristocratic, it must be stressed, needs to be understood not in the social or class sense, but as exception, as distinction, similar to the way in which Barthes, in 1962, considered the Dandy ("Le dandysme et la mode," OC 2:27-31). The aristocratic self is linked to the "délicatesse" of Japanese culture (especially in its food and in the 'lightness' of the Haïku). Specificity now begins to rub up against acts of classification, and "délicatesse" plays a clear part in this singularization. The notion of "délicatesse," dependent on the ethics of "non-vouloir-saisir" (or "NVS") described in the Fragments d'un discours amoureux and in the Comment vivre ensemble lectures, is subsequently theorised in the lectures on Le neutre. Here "NVS" and "délicatesse" are "des sortes de protestations actives ou d'esquives inattendues contre la réduction, non de l'individu (il ne s'agit pas d'une philosophie de l'individualisme) mais de l'individuation," the risk being that the Other "[me] réduit par la parole (souvent bien intentionnée, innocente) à un cas qui relève très normalement d'une explication ou d'une classification générale." Against this, Barthes proposes the "obscène social (l'inclassable)" (Neutre 6466). If the 1970 s see Barthes looking for singularity of the self, this "délicatesse" is often found in literarization, in attempts to turn life into literature.

For example, in 1973, having referred to his own work on Gide's Journal (in 1942) and to his assertion (in 1966) that Proust's life is not reflected in $\dot{A}$ la recherche du temps perdu, but the opposite-_c'est sa vie qui est le texte 
de son œuvre" (Lexique de l'auteur 324)-Barthes moves into the third person to exemplify how this has happened in his own life and work:

Par exemple, cette année (1972-1973), il produit un texte particulier en opérant des sortes de collusions entre des rendez-vous très différents; il voit coup sur coup des sujets surgis de contextes hétéroclites, incompatibles (aller dans une "boîte" au sortir d'un entretien avec un militant communiste); cela brise la loi monotone du discours de vie, cela produit une sorte de charivari textuel. (Lexique de l'auteur 324-25)

This moment points, perhaps obliquely, to a key final theme in his career, "life as text." Introduced by the exceptionalism of the literary-inspired notion of "délicatesse," the "charivari" or clash of different worlds in Barthes's life (in which a visit to a night-club clashes with a discussion about Communism) suggests not simply that he is a "passeur" sliding imperceptibly, subtly, between different worlds, but also that the "passeur" can achieve some form of non-classification, can become "déclassé." This declassified self, atopic if not utopian in socio-political terms, is part of "délicatesse" (it is nearly an anagram of it too!). It is prefigured in $S / Z$ in what Barthes calls "l'inorigine" of wealth, whereby his reading of Balzac's "Sarrasine" categorises the origin of the Lanty family's wealth as a textual mystery (we suspect, as readers, that their fortune comes from the price of La Zambinella's castrato status). But by the 1970s, Barthes seems to be considering one's "inorigine" or lack of socialclass determinism as a utopian state that allows the self to escape classification in any social class. This appreciation of the "inorigine" of wealth, of social determinisms, now becomes, in the late Barthes, the search for what he calls the 'aristocratic' self. Not so much the "souverain" self theorized by Georges Bataille, Barthes's aristocratic self is defined in relation to the other, in relations with others. ${ }^{22}$ In his paper at the Cerisy conference in 1977, Barthes (implicitly) links délicatesse and the déclassé to democracy. Quoting a commentator of Spinoza, Barthes suggests that the democratic is not at all defined as "la réalisation d'une grégarité étouffante," but as “"ce qui devrait produire des âmes aristocratiques" (OC 5:516). By the time of La chambre claire this 'aristocratic' self becomes the "science impossible de l'être unique" (OC 5:847), the unclassifiable radical singularity of the individual, that of his recently deceased and much mourned mother.

\section{Conclusion}

The combinatoire understanding of self, radical in its detail and specificity, now allows us a perspective on oscillation. Marie Gil's use of oscillation in her biography of Barthes seems to deploy a two-term dialectic, without clo- 
sure or synthesis. But her psychoanalytical schema does inevitably lead to a classification of Barthes as "oscillator." We may be persuaded by her suggestion that Barthes oscillates between figures throughout his career (his critique of "Ni-Niism" in Mythologies in the 1950s becomes the positive Neutral of the 1970s, for example). However, it hides not only an essence but also teleology. The teleological aspect of Gil's "essai biographique"- that Barthes's life and writing were always leading up to the tragedy of his mother's demise - resembles, in particular, the "law of revolutions" that Joussain posited in a mechanical and analogical fashion, if not the "sociologie" of forms in Caillois's description of Marxism.

Given that he describes himself as not so much "contradictoire" as "dispersé" (OC 4:717), there is perhaps only one classification of Barthes possible, that is, as essayist and innovator of new essayistic forms. In her study of Barthesian etymology, Hanania quotes Barthes's view in Roland Barthes par Roland Barthes that "le binarisme était pour lui un objet amoureux." To Hanania, this comment suggests that

la dichotomie à l'œuvre dans ses classements était le reflet extériorisé et rhétorique d'une division intime plus générale chez lui, d'un désarroi doctrinal qui se 'traduit' par une ambivalence fondamentale à l'égard de l'écriture. (Hanania 139)

This "désarroi," suggests Hanania, explains "le besoin d'effleurer et l'envie d'affirmer" so typical of Barthes's writing, and is tantamount to "un grand paradoxe entre une revendication de 'fragilité' théorique et des tours de force rhétorique" (40).

It would seem then, despite its claims otherwise, that a psychoanalytical reading of Barthes's life (at least in Gil's version) leads to an essentialized, classified closure, albeit an oscillating one. Is Gil's 'dualism' in relation to Barthes really a "dialectique à deux termes," or does it synthesise him teleologically into a 'totality' that she seems to want to ignore in her own classification? Our reading of the 'early' Barthes's use of Marxism helped to open up questions around analogy, exception, explanation, and metaphor. So do we not need a critique of the totalizing nature of the metaphors of psychoanalysis? One response is to see (and valorize) Barthes as some sort of social psychoanalyst, with one historical example of a political social-psychoanalysis available in Karl Marx's brilliant mot, "All I know is that I am not a Marxist." This dictum is an open dialectic in one sense in that it allows for future methodological and political shifts, but is dialectical in another sense, in that it is located in the time of history that is Marx's life. I am tempted to say for Barthes that there is an ultimate way of expressing the "déclassé," the non- 
classified (and he would certainly appreciate the third-person form we might employ in the following parody of Marx): "Barthes is not - or is not alwaysa Barthesian." This idea is exemplary as the basis for literary and cultural analysis, if not for political and social critique.

\section{University of Leeds}

\section{Notes}

1. Quotations from Barthes's writings are taken from the French versions as they appear either in the five-volume CEuvres completes, Éric Marty, ed. (Paris: Seuil, 2002) or in the posthumous volumes that have been published since 2002. Here, OC 2:781.

2. Marie Gil, Roland Barthes: Au lieu de la vie (Paris: Flammarion, 2012); Roland Barthes, Le neutre. Cours au Collège de France (1977-1978) (Paris: IMEC/Seuil, 2002), 222-23.

3. Gilles Philippe, Bibliographie Barthes (Rome: Memini / Paris: CNRS, 1996); Neil Badmington, ed., Roland Barthes: Critical Evaluations in Cultural Theory (London: Routledge, 2010).

4. In a short fragment from 1929, Georges Bataille links the "déclassé" to the "informe" (Euvres completes, Denis Hollier, ed., [Paris: Gallimard, 1971], 1:217); indeed, though normally referring in French to a class demotion, "déclassé" can also have the rare, more positive meaning of "unclassified," removed from classification or from any social-class attribution.

5. See Gil, Roland Barthes, 20-25, where she describes the "matrice du vide" as the prelude to the "métaphore photographique," the gradual "revelation" in which Barthes's life was always leading up to the death of his mother. In her recent biography (Paris: Seuil, 2015), Tiphaine Samoyault is less inclined to use a psychoanalytical framework to account for the trajectory in Barthes's life.

6. In her hurry to see how the oscillator stops oscillating, following the death of the person who, psychoanalytically, had helped generate his oscillation, Gil seems to deny to Barthes any years, but the last three of his life, outside of the "trou" to which his semi-orphaned status had consigned him. Did Barthes really spend all of his life, up until 1977, flitting purposelessly around in a hole formed by the absence of the father and the determining presence of his mother?

7. In Houdini's Box: On the Arts of Escape (London: Faber, 2001), Adam Phillips shows that though some people try to escape from the hole they find themselves in, others find freedom in a self-imposed confinement.

8. Brian K. Hall, “The Paradoxical Platypus," Bioscience, 49:3 (1999): 211-18; Umberto Eco, in Kant et l'ornithorynque (Paris: Grasset, 1999), suggests that this "étrange animal [...] semble avoir été conçu pour défier toute classification" (62) and provides a useful overview of the prolonged struggle to classify it (246-53).

9. Linnæus appears again in Barthes's 1954 article "Le monde-objet" where, analysing seventeenth-century Dutch painting, Barthes notes how the word "classe," "par un fait exprès," serves two notions, "aussi bien séparés que les classes zoologiques de Linné": that is, the patrician class and the peasant class first, and then their morphological classification within their class; just as in Linnæus's division of animals, suggested Barthes (possibly gesturing towards the racist discourse of the nineteenth-century to which Linnæus's classifications of humans were subsequently mobilized), so classical Dutch painting physically divided its social classes: "chaque classe rassemble les humains, non seulement de même condition sociale, mais aussi de même morphologie" (OC 2:287).

10. André Joussain, La loi des révolutions (Paris: Flammarion, 1950).

11. Roger Caillois, Description du marxisme (Paris: Gallimard, 1950).

12. In evolutionary terms, this structuralist account would be equivalent to showing how the platypus functions as a historic - and very rare - link between mammals and their amphib- 


\section{L'ESPRIT CRÉATEUR}

ian and even aquatic past; according to Eco, it was the British surgeon Everard Home who, in 1812 (long before Darwin), saw the platypus's evolutionary importance (Kant et l'ornithorynque, 249).

13. "[L]e rebut inorganisé des nouvelles informes [...] serait une information monstrueuse, analogue à tous les faits exceptionnels ou insignifiants, bref anomiques, que l'on classe d'ordinaire pudiquement sous la rubrique des Varia, tel l'ornithorynque qui donna tant de souci au malheureux Linné" (OC 2:442).

14. Philip Thody, Roland Barthes: A Conservative Estimate (London: Macmillan, 1977), 116.

15. Barthes puts it neatly in his 1971 interview with Stephen Heath: "pour pouvoir déjouer les codes, il faut entrer dans les codes" (OC 3:1019).

16. See René Lourau, L'instituant contre l'institué (Paris: Anthropos, 1969) and L'analyse institutionnelle (Paris: Minuit, 1971).

17. See Barthes's comment in 1973-1974 on the "espace institutionnel" of the Seminar, in Le lexique de l'auteur (Paris: Seuil, 2010), 52-53: "il faut accepter de jouer avec l'Institution, [...] la subvertir non la contester."

18. Cécile Hanania, Roland Barthes et l'étymologie (Brussels: Peter Lang, 2010).

19. See Ginette Michaud, Lire le fragment: Transfert et théorie de la lecture chez Roland Barthes (Ville LaSalle: Hurtubise, 1989), 50-53; though Réda Bensmaïa astutely distinguishes detail and fragment in Barthes's work by suggesting that the detail is the "inside" of the fragment in The Barthes Effect: The Essay as Reflective Text (Minneapolis: U of Minnesota $P, 1987), 41-46$, especially 43-44.

20. Patrizia Lombardo, "Le dernier livre," L’Esprit Créateur, 22:1 (1982): 79.

21. Roland Barthes, Carnets de voyage en Chine (Paris: Christian Bourgois / IMEC 2009), 73.

22. For Bataille, the sovereign self is one that violently asserts its refusal of power in an excessive, crazed manner. See La méthode de meditation, Euvres complètes (Paris: Gallimard, 1973), 5:221. 